\title{
Miscanthus $\times$ giganteus nutrient concentrations and uptakes in autumn and winter harvests as influenced by soil texture, irrigation and nitrogen fertilization in the Mediterranean
}

\author{
NERI RONCUCCI ${ }^{1} *$, NICOLETTA NASSI O DI NASSO ${ }^{1}$, CRISTIANO TOZZINI ${ }^{1}$, ENRICO \\ BONARI ${ }^{1,2}$ and GIORGIO RAGAGLINI ${ }^{1}$ \\ ${ }^{1}$ Institute of Life Sciences, Scuola Superiore Sant'Anna, Piazza Martiri della Libertà 33, Pisa 56127, Italy, ${ }^{2}$ CRIBE - Centro di \\ Ricerche Interuniversitario Biomasse da Energia, Via Vecchia Livornese 784, Pisa 56122, Italy
}

\begin{abstract}
Fertilization has a great impact on GHG emissions and crop nutrient requirements play an important role on the sustainability of cropping systems. In the case of bioenergy production, low concentration of nutrients in the biomass is also required for specific conversion processes (e.g. combustion). In this work, we investigated the influence of soil texture, irrigation and nitrogen fertilization rate on nitrogen, phosphorus and potassium concentrations and uptakes in Miscanthus $\times$ giganteus when harvested at two different times: early (autumn) and late (winter). Our results confirmed winter harvest to significantly reduce nutrient removals by as much as $80 \%$ compared to autumn. On the other hand, a few attempts have been made to investigate the role of soil texture and irrigation on nutrients in miscanthus biomass, particularly in the Mediterranean. We observed an effect of soil mainly on nutrient concentrations. Similarly, irrigation led to higher nutrient concentrations, while its effect on nutrient uptakes was less straightforward. Overall, the observed differences in miscanthus nutrient uptakes as determined by the crop management (i.e. irrigation and nitrogen fertilization) were highlighted for autumn harvest only, while uptakes in all treatments were lowered to similar values when winter harvest was performed. This study stressed the importance of the time of harvest on nutrient removals regardless of the other management options. Further investigation on the environmental and economic issues should be addressed to support decisions on higher yields-higher nutrient requirements (early harvest) vs. lower yieldslower nutrient requirements (late harvest).
\end{abstract}

Keywords: crop management, energy crop, harvest time, nitrogen fertilization, nutrient content, nutrient cycling, nutrient removal, perennial rhizomatous grass, phosphorus, potassium

Received 24 February 2014; accepted 29 April 2014

\section{Introduction}

Miscanthus (Miscanthus $\times$ giganteus Greef et Deuter) is a promising candidate for bioenergy purposes as it displays a number of positive characters, such as perenniality, high yield potential, low nutrient requirements, soil carbon sequestration and other ecosystem services (Anderson-Teixeira et al., 2009; Chum et al., 2011; Karp \& Richter, 2011; Dohleman et al., 2012; Larsen et al., 2013).

Nutrient requirements play a fundamental role on the sustainability of energy crops since fertilization has a great impact on GHG emissions (Boehmel et al., 2008;

\footnotetext{
*These authors contributed equally to this work.

Correspondence: Neri Roncucci, tel. +39 050 883512, fax +39050 883526, e-mail: n.roncucci@sssup.it
}

Karp \& Shield, 2008; Davis et al., 2013). In fact, the production of nitrogen fertilizers is a particularly high energy demanding process, and gaseous emissions (e.g. $\mathrm{N}_{2} \mathrm{O}$ ) following its application have significant environmental impacts (Crutzen et al., 2008). In addition, phosphorus and potassium are non renewable resources. Although phosphorus uptakes by miscanthus are rather limited (Cadoux et al., 2012), serious concerns have been addressed on phosphorus reserves depletion by Cordell et al. (2009). On the other hand, potassium can be removed from the soil at high rates by miscanthus cultivation (Beale \& Long, 1997; Nassi o Di Nasso et al., 2011a; Cadoux et al., 2012).

Therefore, while being desirable for specific conversion processes (i.e. thermochemical processes) (Monti et al., 2008), a low mineral concentration in biomass is advantageous as it minimizes nutrient removals at harvest, in turn reducing input needs and negative 
environmental impacts (Christian et al., 2008). However, most of the available studies on nutrient concentrations and removals in miscanthus have focused on nitrogen, while only few reported data on phosphorus and potassium (Cadoux et al., 2012). In addition, no studies have been conducted on nutrient removals of young miscanthus plantations in the Mediterranean, yet.

Since perennial grasses remobilize resources from the above- to the belowground organs from mid-summer onwards (Beale \& Long, 1997; Heaton et al., 2009; Dohleman et al., 2012; Nassi o Di Nasso et al., 2013) it is of much importance to assess nutrient dynamics in the aboveground biomass at different harvest times. Moreover, there is no general consensus on the exact nutrient requirements of miscanthus due to interactions between crop management and pedo-climatic condition (Heaton et al., 2009; Cadoux et al., 2013). It is thus fundamental to further deepen the knowledge on miscanthus nutrient uptakes as affected by different crop managements, such as irrigation and fertilization.

To the best of our knowledge no studies have investigated the role of water availability on miscanthus nutrient concentrations and removals, while some did analyze the role of nitrogen fertilization. For instance Kludze et al. (2013) and Baxter et al. (2014) reported that high $\mathrm{N}$ fertilization rates increased $\mathrm{N}$ concentration in miscanthus biomass. On the other hand, occasional and inconsistent differences in aboveground nutrient uptakes as influenced by fertilizer application rate were observed by Christian et al. (2008) and Smith \& Slater (2010). The interaction between date of harvest and N fertilization on miscanthus nitrogen uptake has been reported by Himken et al. (1997) and Strullu et al. (2011)

This study was based on the experimental framework of miscanthus previously described by Roncucci et al. (2014) in the Mediterranean (Pisa, Italy). Here, two main questions were addressed: (i) how soil texture and crop management (i.e. irrigation, nitrogen application rate and harvest time) influence $\mathrm{N}, \mathrm{P}$ and $\mathrm{K}$ concentrations in miscanthus? and (ii) does soil type, irrigation and nitrogen fertilization significantly affect $\mathrm{N}, \mathrm{P}$ and $\mathrm{K}$ uptakes at early (autumn) vs. late (winter) harvest times?

\section{Materials and methods}

\section{Site and trial set up}

The research was carried out at the Interdepartmental Centre for Agro-Ecological Research (CIRAA) in the Pisa coastal plain (central Italy; latitude $43^{\circ} 68^{\prime} \mathrm{N}$, longitude $10^{\circ} 35^{\prime} \mathrm{E} ; 1 \mathrm{~m}$ a.s.l. and 0\% slope) for two consecutive years, i.e. 2011 and 2012. The area, having originated from land reclamation, is characterized by heterogeneous soil textures, with different soils located within few hundred meters one another, and thus provides a particularly suited site for comparing soil effects under the same environmental conditions (e.g. meteorological conditions, water table depth, etc.).

In spring 2010, two adjacent fields characterized by two contrasting soil textures, i.e. silty-clay-loam $(\mathrm{SiC})$ and sandy-loam (SL), were used to carry out two experiments:

- Experiment 1: Three main plots were arranged in the SiC soil and three in the SL soil. Within each main plot, three nitrogen fertilization levels [0 $\left(\mathrm{N}_{0}\right), 50\left(\mathrm{~N}_{50}\right), 100\left(\mathrm{~N}_{100}\right)$ $\mathrm{kg} \mathrm{ha}^{-1}$ ] were randomly assigned as subplots (size $6.5 \times 5.0 \mathrm{~m})$

- Experiment 2 was set up on the SiC soil. Main plots (three replicates) were assigned to two irrigation regimes: $0 \%$ $\left(\mathrm{ET}_{0}\right)$ vs. $75 \%\left(\mathrm{ET}_{75}\right)$ of the potential evapotranspiration. Within each main plot, three nitrogen fertilization levels [0 $\left.\left(\mathrm{N}_{0}\right), 50\left(\mathrm{~N}_{50}\right), 100\left(\mathrm{~N}_{100}\right) \mathrm{kg} \mathrm{ha}{ }^{-1}\right]$ were randomly identified as subplots (size $6.5 \times 5.0 \mathrm{~m}$ ).

Meteorological data were obtained from the closest weather station $(<500 \mathrm{~m}$ from the experimental site). The soil was a Typic Xerofluvent, representative of the lower Arno river plain, characterized by a shallow water table never below a $2.5 \mathrm{~m}$ depth even during the driest periods. The $\mathrm{SiC}$ soil was characterized by $18.1 \%$ sand, $46.4 \%$ silt and $35.5 \%$ clay, $\mathrm{pH} 8.2$ (1 : 1 $\mathrm{w} / \mathrm{v}), 1.8 \%$ organic matter (Walkley-Black), $1.4 \mathrm{~g} \mathrm{~kg}^{-1}$ total nitrogen (Kjeldahl), $69.3 \mathrm{mg} \mathrm{kg}^{-1}$ available phosphorus (Olsen), $223.7 \mathrm{mg} \mathrm{kg}^{-1}$ exchangeable potassium (Dirks and Scheffer), and the SL soil by $78.9 \%$ sand, $11.0 \%$ silt and $10.1 \%$ clay, $\mathrm{pH} 7.7(1: 1 \mathrm{w} / \mathrm{v}), 0.9 \%$ organic matter (Walkley-Black), $0.7 \mathrm{~g} \mathrm{~kg}^{-1}$ total nitrogen (Kjeldahl), $116.9 \mathrm{mg} \mathrm{kg}^{-1}$ available phosphorus (Olsen), $151.7 \mathrm{mg} \mathrm{kg}^{-1}$ exchangeable potassium (Dirks and Scheffer).

Tillage was conducted in the autumn of 2009 by ploughing, followed by rotary harrowing immediately before planting. Crop establishment was carried out on April 22, 2010 using rhizomes, at a density of two plants per $\mathrm{m}^{-2}(1 \times 0.5 \mathrm{~m}$ spacing). No preplant fertilizer was given. Plants were watered throughout the first growing season to get them established. Weeding and pest control were never necessary during the trial.

In both experiments, nitrogen (urea) fertilization treatments were always performed in spring, when crops were 0.20 $0.30 \mathrm{~m}$ tall. In Experiment 2, water was distributed by drip irrigation. Drip irrigation pipes were placed $1 \mathrm{~m}$ apart and positioned in the interrows. The distance of drippers was $30 \mathrm{~cm}$ with a dripper flow rate of 11 per hour. Daily potential evapotranspiration (ETP) was estimated through the FAO PenmanMonteith equation (Allen et al., 1998) from daily climatic data gathered from the nearest weather station (located less that $500 \mathrm{~m}$ from the experimental sites). Irrigation was scheduled every 2 days.

\section{Measurements}

In both Experiments 1 and 2, the aboveground biomass and litter samples collected in autumn (A) (12 October 2011 and 
2 October 2012) and winter (W) (25 January 2011 and 20 February 2012) were used for nutrient analysis. At each harvest time, the aboveground biomass was sampled in a $4 \mathrm{~m}^{2}$ area $\left(2 \times 2 \mathrm{~m}^{2}\right.$ subreplicates $)$ and fresh weight was determined. Border plants from the outer rows were not included in the sampling area. Plant subsamples were partitioned into leaves, stems and inflorescence. After being dried at $60{ }^{\circ} \mathrm{C}$ until constant weight, subsamples were milled to powder (particle size $<297 \mathrm{~mm}$ ) and then used for chemical analysis.

Nitrogen concentration $\left(\mathrm{g} \mathrm{kg}^{-1}\right)$ was calculated using the Kjeldahl method (Bradstreet, 1965), while phosphorus and potassium concentrations were determined by spectrophotometric analysis and flame photometry, respectively.

Nutrient uptake $\left(\mathrm{kg} \mathrm{ha}^{-1}\right)$ in each aboveground plant organ was calculated as the product of its nutrient concentration and its dry biomass yield. Miscanthus aboveground nutrient uptake was calculated as the sum of the nutrient uptake in leaves, stems and inflorescences. Nutrient content $\left(\mathrm{kg} \mathrm{ha}^{-1}\right)$ in litter was determined as the product of the litter per unit of area and its nutrient concentration.

Autumn remobilization (i.e. nutrients remobilized from the aboveground biomass to the rhizome) was derived by subtracting the aboveground nutrient uptake at W (late) harvest and the nutrient content in litter from the aboveground nutrient uptake at A (early) harvest, following the approach outlined by Strullu et al. (2011).

\section{Statistical analysis}

Data were analyzed by a split-split plot ANOvA to evaluate the effect of the main plot (i.e. soil texture in Experiment 1, irrigation in Experiment 2), of the subplot (nitrogen fertilization) and of the subsubplot (time of harvest) on nutrient concentrations and uptakes in miscanthus aboveground biomass (Gomez \& Gomez, 1984). Tukey's HSD post hoc test was used to separate means. The statistical analysis was performed with $\mathrm{R}$ software (R Core Team, 2013) and the agricolae package (de Mendiburu, 2013).

\section{Results}

This study focused on nutrients in miscanthus aboveground biomass, while dry biomass yield data have already been described by Roncucci et al. (2014). In Experiment 1 dry biomass yields were lower in SL compared to $\mathrm{SiC}$ soil (around $21 \mathrm{vs.} 7 \mathrm{Mg} \mathrm{ha}^{-1}$ as the 2 year average). Overall, a $36 \%$ yield reduction was observed when the harvest was delayed from autumn to winter (Table 1). In Experiment 2, the irrigation had no effect on miscanthus dry yield (around $22 \mathrm{Mg} \mathrm{ha}^{-1}$ as averaged over the two irrigation levels and years of investigation). An effect of the nitrogen fertilization rate was observed in 2011, when miscanthus aboveground dry yield increased of about $5 \mathrm{Mg} \mathrm{ha}^{-1}$ from $\mathrm{N}_{0}$ to $\mathrm{N}_{100}$. In both years the date of harvest substantially affected miscanthus dry yields (around 26 and $17 \mathrm{Mg} \mathrm{ha}^{-1}$ in autumn and winter harvests respectively) (Table 2).

\section{Experiment 1 - Contrasting soil textures}

Nutrient concentrations were significantly affected by the analyzed factors and their interactions in both 2011 and 2012. Overall, nutrient concentrations in the harvestable aboveground biomass were higher in SL than SiC soil $(P=0.001$ and $P=0.011$ for $[N], P=0.001$ and $P=0.001$ for $[\mathrm{P}], P<0.001$ and $P<0.001$ for $[\mathrm{K}]$, in 2011 and 2012, respectively) and at A compared to $W$ harvest $(P<0.001$ for $[\mathrm{N}],[\mathrm{P}]$ and $[\mathrm{K}]$ in both 2011 and 2012). Moreover, $N$ and $K$ concentrations increased with increasing $\mathrm{N}$ fertilization rates $(P=0.002$ and $P<0.001$ for [N], $P<0.001$ and $P<0.001$ for $[\mathrm{K}]$, in 2011 and 2012, respectively), while the opposite was observed for P concentration $(P<0.001$ in both 2011 and 2012). Averaged over the 2 years of investigation, miscanthus aboveground nutrient concentrations in SL soil were

Table 1 Aboveground dry yield and nutrient concentrations in Experiment 1 for the second (2011) and third (2012) growing seasons. $\mathrm{SiC}$ and SL represent the silty-clay-loam and the sandy-loam soils; A and W represent autumn and winter harvests. Data are averaged over the three nitrogen fertilization rates. Standard errors are given in brackets $(n=3)$

\begin{tabular}{|c|c|c|c|c|c|c|}
\hline \multicolumn{3}{|c|}{ Treatments } & \multirow{2}{*}{$\begin{array}{l}\begin{array}{l}\text { Aboveground } \\
\text { dry yield }\left(\mathrm{Mg} \mathrm{ha}^{-1}\right)\end{array} \\
21.6( \pm 1.2)\end{array}$} & \multirow{2}{*}{$\frac{\mathrm{N}\left(\mathrm{g} \mathrm{kg}^{-1}\right)}{4.16( \pm 0.13)}$} & \multirow{2}{*}{$\frac{P\left(\mathrm{~g} \mathrm{~kg}^{-1}\right)}{0.78( \pm 0.06)}$} & \multirow{2}{*}{$\frac{\mathrm{K}\left(\mathrm{g} \mathrm{kg}^{-1}\right)}{5.84( \pm 0.25)}$} \\
\hline 2011 & $\mathrm{SiC}$ & A & & & & \\
\hline & & W & $15.5( \pm 1.4)$ & $1.28( \pm 0.04)$ & $0.39( \pm 0.02)$ & $2.85( \pm 0.15)$ \\
\hline & SL & A & $13.3( \pm 1.2)$ & $6.30( \pm 0.32)$ & $1.15( \pm 0.13)$ & $10.56( \pm 0.54)$ \\
\hline & & W & $7.9( \pm 0.7)$ & $2.05( \pm 0.07)$ & $0.53( \pm 0.02)$ & $5.03( \pm 0.26)$ \\
\hline \multirow[t]{4}{*}{2012} & $\mathrm{SiC}$ & A & $29.5( \pm 1.9)$ & $4.12( \pm 0.13)$ & $0.72( \pm 0.03)$ & $7.38( \pm 0.09)$ \\
\hline & & W & $17.5( \pm 1.6)$ & $1.47( \pm 0.04)$ & $0.44( \pm 0.10)$ & $3.93( \pm 0.17)$ \\
\hline & $\mathrm{SL}^{*}$ & A & $4.3( \pm 0.5)$ & $3.55( \pm 0.48)$ & $0.35( \pm 0.04)$ & $4.3( \pm 0.23)$ \\
\hline & & W & $2.8( \pm 0.2)$ & & & \\
\hline
\end{tabular}

*In 2012 miscanthus growing in SL soil was severely influenced by the summer drought which led to premature aboveground senescence (Roncucci et al., 2014). Biomass samples for chemical analysis were collected at complete senescence. 
Table 2 Aboveground dry yield and nutrient concentrations in Experiment 2 for the second (2011) and third (2012) growing seasons. $\mathrm{N}_{0}, \mathrm{~N}_{50}, \mathrm{~N}_{100}$ represent 0,50 and $100 \mathrm{~kg} \mathrm{~N} \mathrm{ha}^{-1}$, respectively; A and $\mathrm{W}$ represent autumn and winter harvests. Data are averaged over the two irrigation regimes. Standard errors are given in brackets $(n=3)$

\begin{tabular}{|c|c|c|c|c|c|c|}
\hline & & & $\begin{array}{l}\text { Aboveground dry } \\
\text { yield }\left(\mathrm{Mg} \mathrm{ha}^{-1}\right)\end{array}$ & $\mathrm{N}\left(\mathrm{g} \mathrm{kg}^{-1}\right)$ & $\mathrm{P}\left(\mathrm{g} \mathrm{kg}^{-1}\right)$ & $\mathrm{K}\left(\mathrm{g} \mathrm{kg}^{-1}\right)$ \\
\hline \multirow[t]{6}{*}{2011} & \multirow[t]{2}{*}{$\mathrm{N}_{0}$} & $\mathrm{~A}$ & $20.0( \pm 2.1)$ & $4.55( \pm 0.14)$ & $1.02( \pm 0.01)$ & $6.54( \pm 0.08)$ \\
\hline & & W & $13.3( \pm 2.0)$ & $1.41( \pm 0.10)$ & $0.41( \pm 0.05)$ & $3.07( \pm 0.35)$ \\
\hline & \multirow[t]{2}{*}{$\mathrm{N}_{50}$} & A & $24.4( \pm 1.9)$ & $4.13( \pm 0.21)$ & $0.73( \pm 0.02)$ & $5.56( \pm 0.31)$ \\
\hline & & W & $17.3( \pm 2.2)$ & $1.34( \pm 0.01)$ & $0.47( \pm 0.01)$ & $3.23( \pm 0.02)$ \\
\hline & \multirow[t]{2}{*}{$\mathrm{N}_{100}$} & A & $25.1( \pm 3.1)$ & $5.40( \pm 0.48)$ & $0.72( \pm 0.04)$ & $8.27( \pm 0.89)$ \\
\hline & & W & $17.5( \pm 1.5)$ & $1.48( \pm 0.09)$ & $0.54( \pm 0.06)$ & $3.50( \pm 0.20)$ \\
\hline \multirow[t]{6}{*}{2012} & \multirow[t]{2}{*}{$\mathrm{N}_{0}$} & A & $27.3( \pm 2.9)$ & $4.14( \pm 0.19)$ & $0.78( \pm 0.04)$ & $8.60( \pm 0.51)$ \\
\hline & & W & $16.8( \pm 1.7)$ & $1.57( \pm 0.02)$ & $0.69( \pm 0.06)$ & $3.53( \pm 0.05)$ \\
\hline & \multirow[t]{2}{*}{$\mathrm{N}_{50}$} & A & $29.4( \pm 2.5)$ & $4.45( \pm 0.19)$ & $0.82( \pm 0.01)$ & $7.45( \pm 0.19)$ \\
\hline & & W & $20.1( \pm 2.2)$ & $1.36( \pm 0.04)$ & $0.34( \pm 0.01)$ & $4.69( \pm 0.05)$ \\
\hline & \multirow[t]{2}{*}{$\mathrm{N}_{100}$} & A & $30.3( \pm 2.6)$ & $5.00( \pm 0.36)$ & $0.69( \pm 0.04)$ & $8.14( \pm 0.24)$ \\
\hline & & W & $17.4( \pm 1.7)$ & $1.61( \pm 0.11)$ & $0.13( \pm 0.01)$ & $4.04( \pm 0.11)$ \\
\hline
\end{tabular}

around $3.9 \mathrm{~g} \mathrm{~N} \mathrm{~kg}^{-1}, 0.6 \mathrm{~g} \mathrm{P} \mathrm{kg}^{-1}$ and $6.1 \mathrm{~g} \mathrm{~K} \mathrm{~kg}^{-1}$, while in $\mathrm{SiC}$ soil around $2.8 \mathrm{~g} \mathrm{~N} \mathrm{~kg}^{-1}, 0.6 \mathrm{~g} \mathrm{P} \mathrm{kg}^{-1}$ and $5.0 \mathrm{~g} \mathrm{~K} \mathrm{~kg}^{-1}$ (Table 1). When delaying from $\mathrm{A}$ to $\mathrm{W}$ harvest $\mathrm{N}, \mathrm{P}$ and $\mathrm{K}$ concentrations were reduced from $4.5 \mathrm{~g}$ $\mathrm{N} \mathrm{kg}^{-1}, 0.8 \mathrm{~g} \mathrm{P} \mathrm{kg}^{-1}, 7.0 \mathrm{~g} \mathrm{~K} \mathrm{~kg}^{-1}$ to $2.1 \mathrm{~g} \mathrm{~N} \mathrm{~kg}^{-1}$, $0.4 \mathrm{~g} \mathrm{P} \mathrm{kg}^{-1}, 4.0 \mathrm{~g} \mathrm{~K} \mathrm{~kg}^{-1}$, respectively (Table 1). In addition, increasing $\mathrm{N}$ fertilization doses from 0 to $100 \mathrm{~kg} \mathrm{~N} \mathrm{ha}{ }^{-1} \mathrm{~N}$ and $\mathrm{K}$ concentrations increased from around 2.9 to $4.0 \mathrm{~g} \mathrm{~N} \mathrm{~kg}^{-1}$ and from 5.3 to $5.8 \mathrm{~g} \mathrm{~K} \mathrm{~kg}^{-1}$, while $\mathrm{P}$ concentration decreased from 0.7 to $0.5 \mathrm{~g}$ $\mathrm{P} \mathrm{kg}^{-1}$ (data not shown).

In both years of investigation, the time of harvest was the most relevant factor in influencing miscanthus nutrient uptakes (Table S1). On average, late (W) harvests led to a reduction in nitrogen uptake of around $80 \%$, and in both phosphorus and potassium uptakes of about $70 \%$ as compared to early (A) harvests. For all nutrients, an interaction between harvest time and nitrogen fertilization level was revealed during the second (2011) year of growth, and between harvest time and soil texture during the third (2012) growing year. In fact, in 2011, when crops receiving $100 \mathrm{~kg} \mathrm{~N}$ ha $^{-1}$ were harvested in $\mathrm{A}$ they displayed the highest $\mathrm{N}$ and $\mathrm{K}$ uptakes (around 100 and $160 \mathrm{~kg} \mathrm{ha}^{-1}$, respectively) (Fig. 1a, c), while the lowest $\mathrm{P}$ uptake (13 $\mathrm{kg} \mathrm{ha}^{-1}$ ) (Fig. 1b). On the other hand, when harvest was performed in $\mathrm{W}$, all nutrient uptakes were substantially reduced to 18,5 , $42 \mathrm{~kg} \mathrm{ha}^{-1}$ for $\mathrm{N}, \mathrm{P}$ and $\mathrm{K}$, irrespectively of the nitrogen fertilization rate. In 2012, miscanthus in SiC soil exhibited different nutrient uptakes between A (122, 21, $218 \mathrm{~kg} \mathrm{ha}^{-1}$ for $\mathrm{N}, \mathrm{P}$ and $\mathrm{K}$, respectively) and $\mathrm{W}(26,7$, $69 \mathrm{~kg} \mathrm{ha}^{-1}$ for N, P and K, respectively) harvests, while crop growing on SL soil showed similar nutrient uptakes between $\mathrm{A}$ and $\mathrm{W}$ harvests (on average 12, 1 and $16 \mathrm{~kg} \mathrm{ha}^{-1}$ for N, P and K, respectively) (Fig. 2).
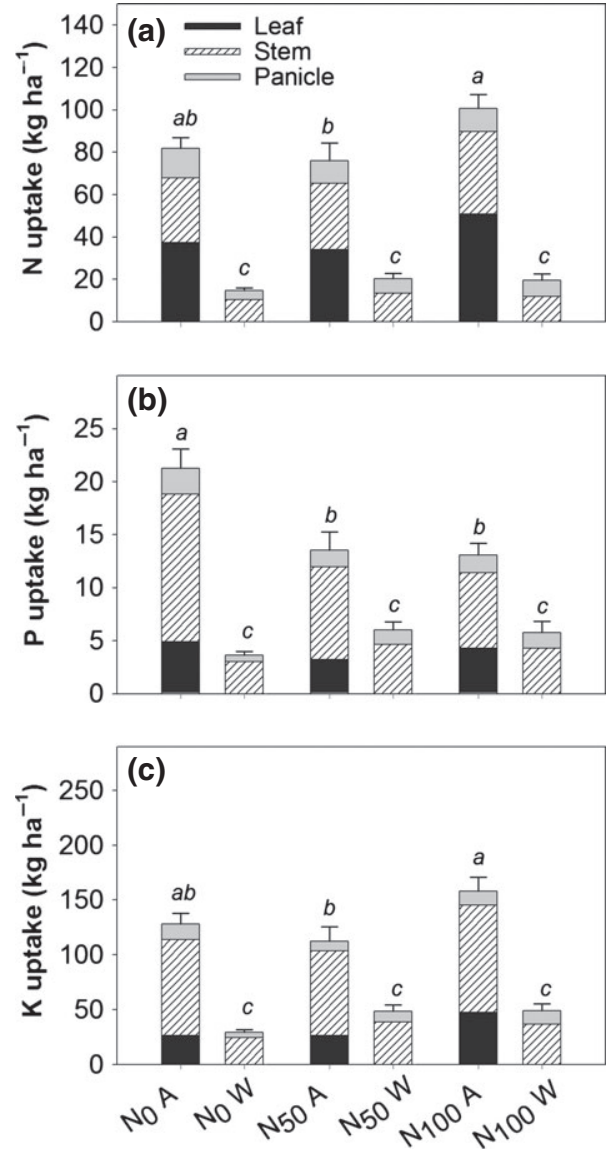

Fig. 1 Interaction between $\mathrm{N}$ fertilization rate and harvest time in Experiment 1 for the second year of growth (2011). Variation in (a) nitrogen, (b) phosphorus and (c) potassium uptakes in miscanthus aboveground components. $\mathrm{N}_{0}, \mathrm{~N}_{50}, \mathrm{~N}_{100}$ represent 0,50 and $100 \mathrm{~kg} \mathrm{~N} \mathrm{ha}^{-1}$, respectively. A and $\mathrm{W}$ represent early (autumn) and late (winter) harvests. Different letters indicate significant differences at $P<0.05$. Vertical bars represent the SE $(n=3)$. 

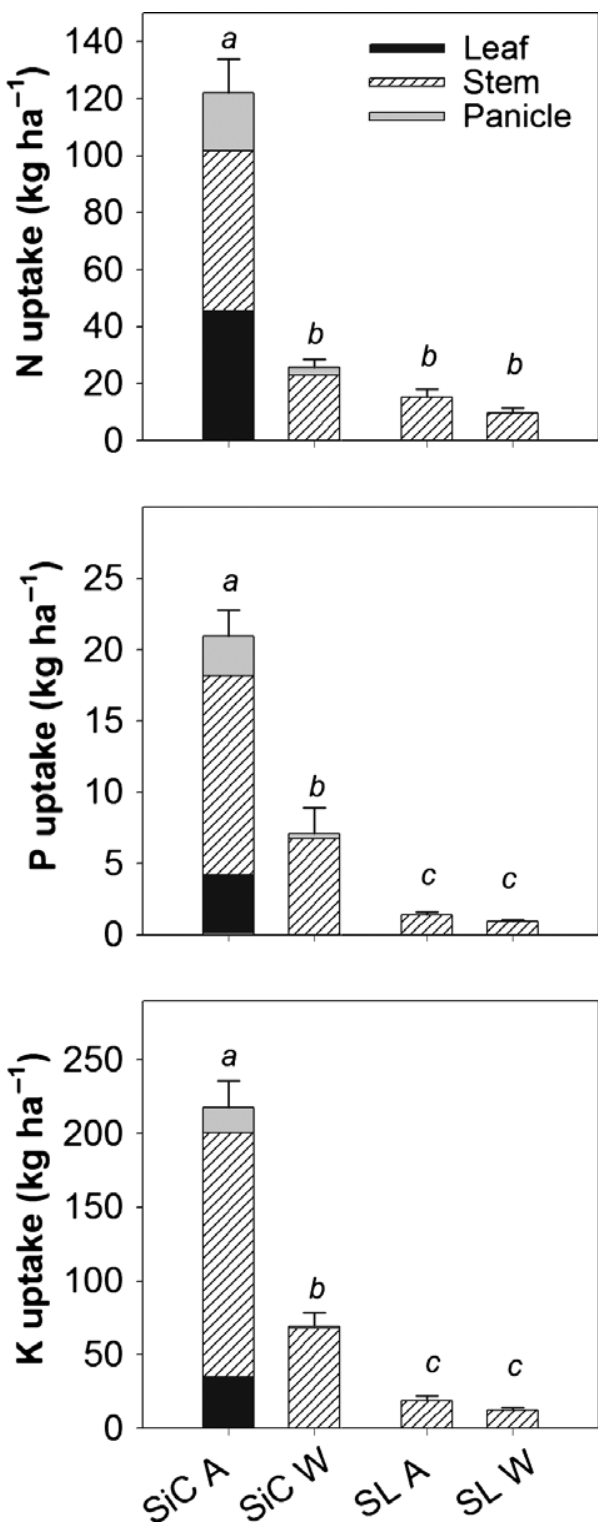

Fig. 2 Interaction between soil texture and harvest time in Experiment 1 for the third year of growth (2012). Variation in nitrogen, phosphorus and potassium uptakes in miscanthus aboveground components. SiC and SL represent silty-clay-loam and sandy-loam soils, respectively. $\mathrm{A}$ and $\mathrm{W}$ represent early (autumn) and late (winter) harvests. Different letters indicate significant differences at $P<0.05$. Vertical bars represent the SE $(n=3)$.

\section{Experiment 2 - Contrasting irrigation regimes}

In general, the effect of the irrigation regime appeared negligible for $\mathrm{N}$ concentration $(P=0.051$ and $P=0.108$ in 2011 and 2012) while it had a partial influence on $P$ $(P=0.005$ in 2011 and not significant in 2012), and an influence on $\mathrm{K}(P<0.001$ and $P=0.003$ in 2011 and 2012, respectively). Moreover, a significant influence of both the harvest time $[P<0.001$ for $(\mathrm{N}),(\mathrm{P})$ an $(\mathrm{K})$ in both years) and the $\mathrm{N}$ fertilization rate $[P<0.001$ for $(\mathrm{N}),(\mathrm{P})$ an $(\mathrm{K})$ in both years but for $(\mathrm{N})$ in 2012 when $P<0.012]$ was highlighted on the three macronutrient concentrations. The only exception was represented by the effect of the nitrogen fertilization on $\mathrm{K}$ concentration in 2012 when no differences among levels were observed $(P=0.858)$. Averaged over the 2 years, miscanthus aboveground $\mathrm{N}$ concentration stood around $3.0 \mathrm{~g} \mathrm{~N} \mathrm{~kg}^{-1}$ in both irrigation regimes. Conversely, aboveground concentrations of $\mathrm{P}$ and $\mathrm{K}$ were slightly higher in $\mathrm{ET}_{75}\left(0.7 \mathrm{~g} \mathrm{P} \mathrm{kg}^{-1}\right.$ and $\left.6.1 \mathrm{~g} \mathrm{~K} \mathrm{~kg}^{-1}\right)$ than in $\mathrm{ET}_{0}\left(0.6 \mathrm{~g} \mathrm{P} \mathrm{kg}^{-1}\right.$ and $5.0 \mathrm{~g} \mathrm{~K} \mathrm{~kg}^{-1}$ ) (data not shown). Delaying the harvest to winter nearly halved $\mathrm{P}$ and $\mathrm{K}$ concentrations (from 0.8 to $0.4 \mathrm{~g} \mathrm{P} \mathrm{kg}^{-1}$ and from 7.4 to $3.7 \mathrm{~g} \mathrm{~K} \mathrm{~kg}^{-1}$, in $\mathrm{A}$ and $\mathrm{W}$ respectively) and reduced by threefold the $\mathrm{N}$ concentration (from 4.6 to $1.5 \mathrm{~g}$ $\mathrm{N} \mathrm{kg}^{-1}$ in A and $\mathrm{W}$ respectively) (Table 2). Averaged over the 2 years and harvest dates, crop receiving the highest $\mathrm{N}$ fertilization rate $\left(\mathrm{N}_{100}\right)$ showed the highest $\mathrm{N}$ and $\mathrm{K}$ concentrations $\left(3.4 \mathrm{~g} \mathrm{~N} \mathrm{~kg}^{-1}\right.$ and $6.0 \mathrm{~g}$ $\left.\mathrm{K} \mathrm{kg}^{-1}\right)$ and the lowest $\mathrm{P}$ concentration $\left(0.5 \mathrm{~g} \mathrm{P} \mathrm{kg}^{-1}\right)$ (Table 2).

The date of harvest was the most important factor in determining significant differences in crop nutrient uptakes (Table S2). Averaged over 2011 and 2012, delayed harvest to winter time reduced $\mathrm{N}, \mathrm{P}$ and $\mathrm{K}$ uptakes in the aboveground biomass of about $-95,-13$ and $-133 \mathrm{~kg} \mathrm{ha}^{-1}$, respectively as compared to autumn harvest (Fig. 3). For the second growing season (2011), increasing nitrogen fertilization level determined higher $\mathrm{N}$ and $\mathrm{K}$ uptakes in the aboveground biomass ( $+47 \%$ and $+59 \%$, respectively) (Fig. $4 a$, b), while no clear relationship was found between $\mathrm{P}$ uptake and nitrogen fertilization rate (data not shown). In addition, two significant interactions were observed in 2011: between harvest time and nitrogen fertilization rate, and between harvest time and irrigation. In fact, when miscanthus receiving $100 \mathrm{~kg} \mathrm{~N} \mathrm{ha}^{-1}\left(\mathrm{~N}_{100}\right)$ or irrigation water $\left(\mathrm{ET}_{75}\right)$ was harvested early in the season (A) it displayed the highest $\mathrm{N}$ and $\mathrm{K}$ uptakes (around $130 \mathrm{~kg}$ $\mathrm{N} \mathrm{ha}^{-1}$ and $200 \mathrm{~kg} \mathrm{~K} \mathrm{ha}^{-1}$ on average). Conversely, when harvest was performed in winter (W), nutrient uptakes in all treatments were lowered to similar values (around 22, 8, $53 \mathrm{~kg} \mathrm{ha}^{-1}$ for $\mathrm{N}, \mathrm{P}$ and $\mathrm{K}$, respectively) (Fig. 4c-f).

For the third growing year (2012), N and K uptakes were influenced only by the date of harvest (Table S2). Although a small increase in $\mathrm{N}$ and $\mathrm{K}$ uptakes was observed at the highest nitrogen fertilization rate $(+27 \%$ and $+7 \%$, respectively), treatments were not significantly different each other (data not shown). Conversely, P uptake decreased significantly when receiving the highest nitrogen fertilization rate 

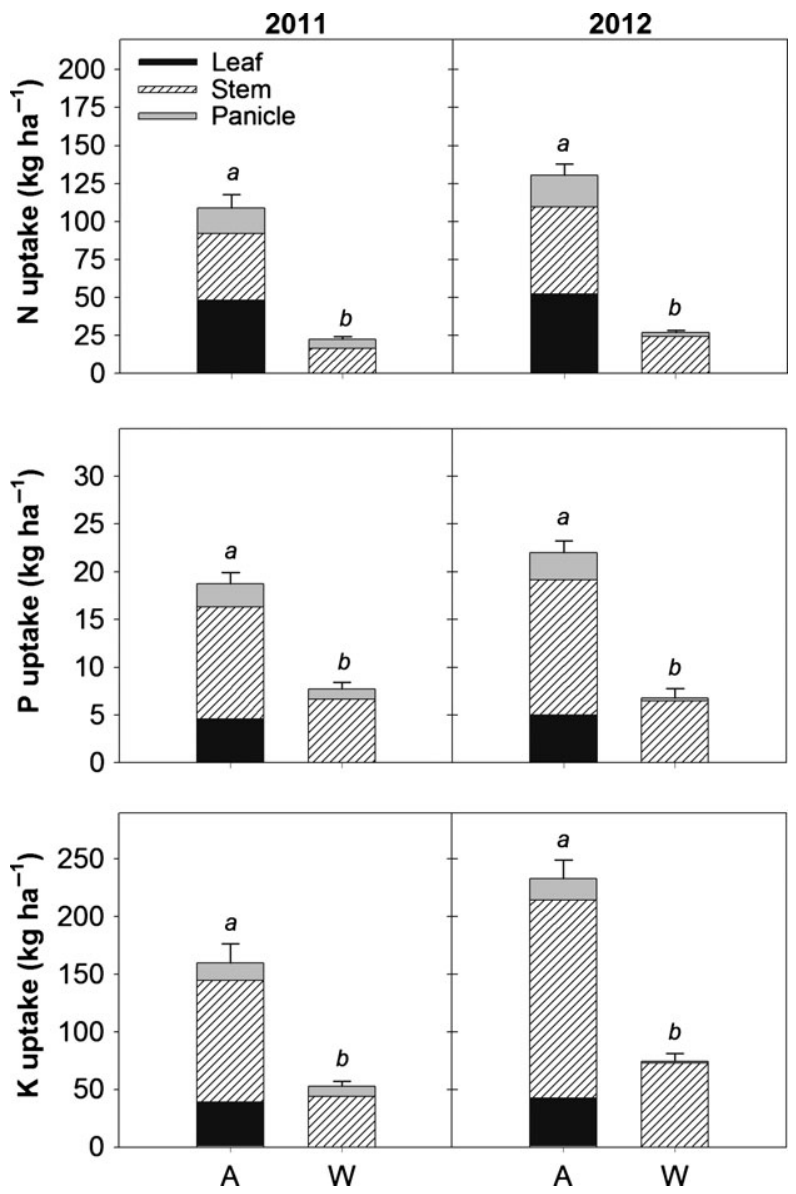

Fig. 3 Effect of the harvest time on miscanthus nutrient uptakes for the second (2011) and third (2012) year of growth in Experiment 2 (i.e. $\mathrm{ET}_{0}$ vs. $\mathrm{ET}_{75}$ on $\mathrm{SiC}$ soil). A and $\mathrm{W}$ represent early (autumn) and late (winter) harvests. Different letters indicate significant differences at $P<0.05$. Vertical bars represent the SE $(n=3)$.

(from $16 \mathrm{~kg} \mathrm{ha}^{-1}$ in $\mathrm{N}_{0}$ and $\mathrm{N}_{50}$ to $11 \mathrm{~kg} \mathrm{ha}^{-1}$ in $\mathrm{N}_{100}$ ) (Fig. 5a). This pattern was particularly marked in $\mathrm{W}$ time $\left(2 \mathrm{~kg} \mathrm{ha}^{-1}\right.$ in $\mathrm{N}_{100}$ ) and led to a nitrogen fertilization rate $\times$ harvest time interaction (Fig. 5b).

Table 3 reports the dynamic of the three macronutrients in the aboveground biomass, together with the nutrients recycled to soil through litterfall and the estimated autumn remobilization from the aboveground to belowground biomass. Results highlighted a rather similar dynamics of all macronutrient. In fact, miscanthus aboveground $\mathrm{N}, \mathrm{P}$ and $\mathrm{K}$ uptakes at $\mathrm{W}$ time had values corresponding to around $21 \%, 34 \%$ and $33 \%$ of those recorded at $\mathrm{A}$ harvest. Compared to an early harvest, nearly $17 \%, 7 \%$ and $7 \%$ of $\mathrm{N}, \mathrm{P}$ and $\mathrm{K}$ were found on top of the soil in winter owing to the aboveground litter. Remobilization of nutrients from above- to belowground organs due to delayed harvest stood at around $60 \%$.

\section{Discussion}

The aim of this study was to investigate, at different harvest times, miscanthus nutrient dynamics in response to different soil textures, irrigation and nitrogen fertilization. The two main questions addressed are now discussed.

How soil texture and crop management influence $N, P$ and $K$ concentrations in miscanthus?

In their review, Cadoux et al. (2012) reported nutrient concentrations at the stage of maximum aboveground biomass (October on average) to vary between 4.4 and $6.9 \mathrm{~g} \mathrm{~kg}^{-1}$ for nitrogen, between 7.7 and $11.9 \mathrm{~g} \mathrm{~kg}^{-1}$ for potassium, and to be around $0.8 \mathrm{~g} \mathrm{~kg}^{-1}$ for phosphorus. Our values in autumn are thus close to the lower end of the literature range. Conversely, when winter harvest is considered the observed $\mathrm{N}, \mathrm{P}$ and $\mathrm{K}$ concentrations are lower than the range reported by Cadoux et al. (2012).

It is well established in literature how miscanthus mineral concentration in the aboveground biomass declines progressively from autumn to winter (Beale \& Long, 1997; Himken et al., 1997; Christian \& Riche, 1998; Lewandowski et al., 2003a; Nassi o Di Nasso et al., 2011b; Dohleman et al., 2012). Our results highlighted a reduction in nutrient concentrations from $\mathrm{A}$ to $\mathrm{W}$ harvests which is consistent with literature data. For instance, Kahle et al. (2001) reported biomass N, P and $\mathrm{K}$ concentration in winter to be $61 \%, 64 \%$ and $55 \%$ of that in autumn. However, the slightly lower values we observed for nitrogen concentration could be possibly linked to the different climatic conditions of the sites. In fact, Lewandowski et al. (2003b) found a more pronounced decrease in $\mathrm{N}$ concentrations in southern Europe as compared to northern sites.

To date no reports are available on the possible role of different soil texture and irrigation regime on nutrient concentrations in miscanthus. The higher nutrient concentrations we generally observed in the SL soil were probably due to the slower growth rate of miscanthus which, in turn, may have prevented the dilution effect of nutrients in the biomass (Alam, 1999). On the other hand, our results highlighted a higher concentration of some nutrients in miscanthus receiving irrigation. This is consistent with common understanding of plant-soil relationships and crop physiological responses. In fact, irrigation water can directly supply some nutrients and indirectly increase nutrient accessibility to roots through enhancing their movement in soil (Chapin, 1991; Lambers et al., 2008).

Overall, minerals play an important role in affecting biomass combustion quality, and maximum thresholds of mineral concentrations in biomass have been given 

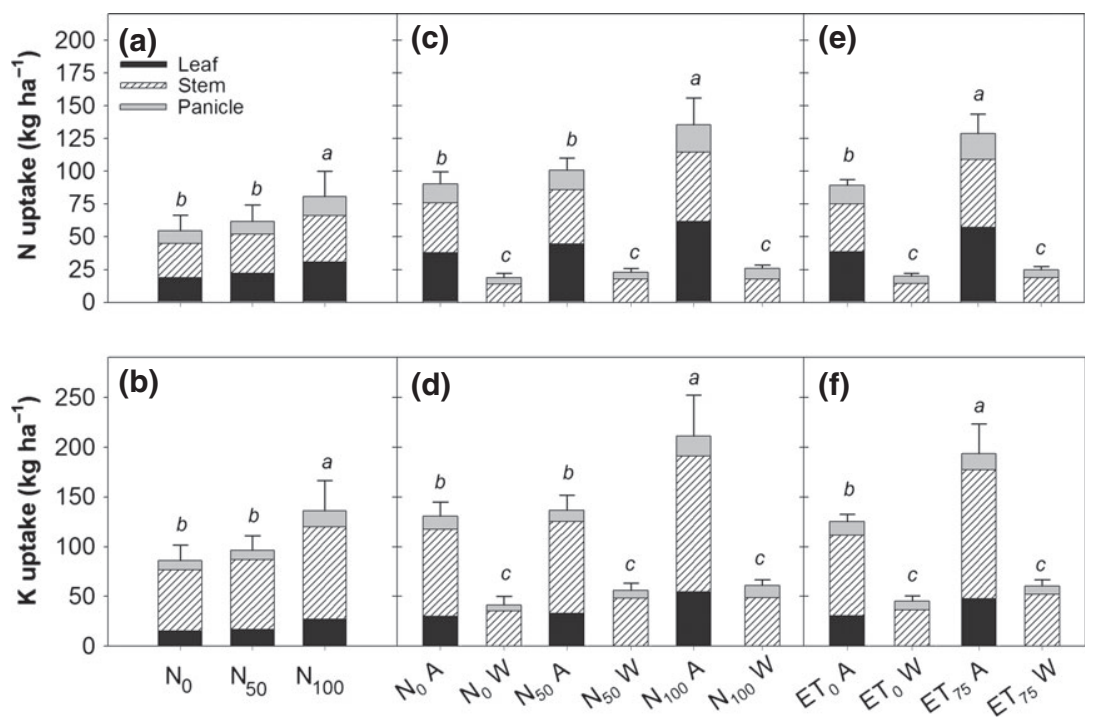

Fig. 4 Variation in nitrogen and potassium uptakes in miscanthus aboveground components in Experiment 2 for the second year of growth (2011). (a, b) effect of the $\mathrm{N}$ fertilization rate (data averaged over the two harvest dates); (c, d) interaction between $\mathrm{N}$ fertilization rate and harvest time; (e, f) interaction between irrigation level and harvest time. $\mathrm{N}_{0}, \mathrm{~N}_{50}, \mathrm{~N}_{100}$ represent 0,50 and $100 \mathrm{~kg} \mathrm{~N}$ ha ${ }^{-1}$, respectively; A and $\mathrm{W}$ are early (autumn) and late (winter) harvests; $\mathrm{ET}_{0}$ and $\mathrm{ET}_{75}$ represent treatments receiving no irrigation and $75 \%$ restitution of the potential evapotranspiration. Different letters indicate significant differences at $P<0.05$. Vertical bars represent the SE $(n=3)$.

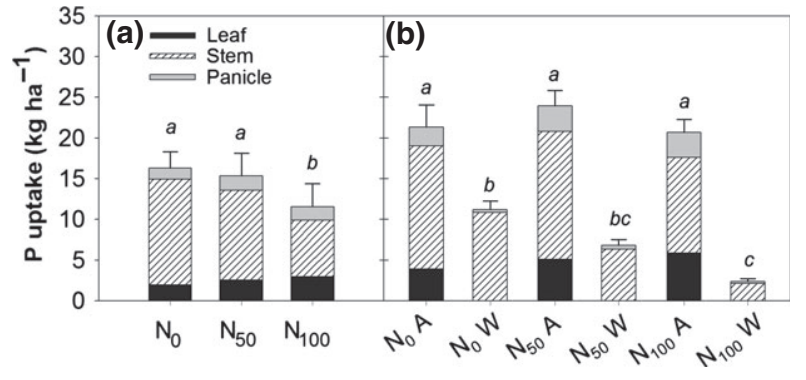

Fig. 5 Effect of the $\mathrm{N}$ fertilization level on phosphorus uptakes in miscanthus aboveground components in Experiment 2 for the third year of growth (2012). $\mathrm{N}_{0}, \mathrm{~N}_{50}, \mathrm{~N}_{100}$ represent 0,50 and $100 \mathrm{~kg} \mathrm{~N}^{-1}$, respectively; A and $\mathrm{W}$ are early (autumn) and late (winter) harvests. Different letters indicate significant differences at $P<0.05$. Vertical bars represent the SE $(n=3)$.

by Lewandowski \& Kicherer (1997), Monti et al. (2008) and Smith \& Slater (2011). These thresholds vary from 1 to $10 \mathrm{~g} \mathrm{~kg}^{-1}$ ( $<6 \mathrm{~g} \mathrm{~kg}^{-1}$ in general) for nitrogen and are around $2 \mathrm{~g} \mathrm{~kg}^{-1}$ for potassium. No combustion problems associated with phosphorus have been reported (Smith \& Slater, 2011). The values experienced in this study highlighted that $\mathrm{N}$ concentration was rather low (always less than $5 \mathrm{~g} \mathrm{~kg}^{-1}$ ), while $\mathrm{K}$ concentration exceeded the threshold limit, in winter time as well. In addition, our results reiterates findings reported by Schwarz et al. (1994), Kludze et al. (2013) and Baxter et al. (2014) who observed a significant effect of the nitrogen fertilization on $\mathrm{N}$ concentration in miscanthus aboveground biomass. Therefore, keeping the nitrogen fertilization rate the lowest possible can have beneficial consequences on biomass quality. However, the variability in the pedo-climatic conditions among sites may mask the effect of crop managements on nutrient concentrations (Lewandowski et al., 2000).

Does soil type, irrigation and nitrogen fertilization significantly affect N, P and K uptakes at early (autumn) vs. late (winter) harvest times?

In terms of nutrient uptakes most of the available studies have concentrated on $\mathrm{N}$, while only a few have reported data on P and K (Cadoux et al., 2012). Moreover, no studies have investigated the dynamic of nutrients of young miscanthus plantation in the Mediterranean. The only peer-reviewed study is the one by Nassi o Di Nasso et al. (2011b) who analyzed the nutrient dynamics on a mature stand of miscanthus in central Italy. Since nutrient uptake derives from the product of nutrient concentration and crop yield, peak uptakes in miscanthus are generally observed in summer (July-August), then nutrients approach a minimum in winter (Beale \& Long, 1997; Himken et al., 1997; Christian et al., 2008; Heaton et al., 2009; Nassi o Di Nasso et al., 2011a, b; Dohleman et al., 2012).

Among the tested treatments, our results confirmed the primary role of the harvest time on nutrient uptakes 
Table 3 Remobilization of nitrogen $(\mathrm{N})$, phosphorus $(\mathrm{P})$ and potassium $(\mathrm{K})$ in miscanthus grown under contrasting irrigation regimes (Experiment 2) during the second (2011) and third (2012) year of growth. $\mathrm{ET}_{0}$ and $\mathrm{ET}_{75}$ represent treatments receiving no irrigation and 75\% restitution of the potential evapotranspiration, respectively. Reported values are in $\mathrm{kg} \mathrm{ha}^{-1}$

\begin{tabular}{|c|c|c|c|c|c|c|c|c|c|c|c|c|}
\hline & & & \multicolumn{4}{|c|}{$\begin{array}{l}\text { Nutrient uptakes at early (autumn) } \\
\text { harvest }\end{array}$} & \multicolumn{4}{|c|}{$\begin{array}{l}\text { Nutrient uptakes at late (winter) } \\
\text { harvest }\end{array}$} & \multirow{2}{*}{$\begin{array}{l}\text { Nutrient } \\
\text { content in } \\
\text { litterfall (i) }\end{array}$} & \multirow{2}{*}{$\begin{array}{l}\text { Autumn } \\
\text { remobilization } \\
(\mathrm{j}=\mathrm{d}-\mathrm{h}-\mathrm{i})\end{array}$} \\
\hline & & & $\begin{array}{l}\text { Leaf } \\
\text { (a) }\end{array}$ & $\begin{array}{l}\text { Stem } \\
\text { (b) }\end{array}$ & $\begin{array}{l}\text { Panicle } \\
\text { (c) }\end{array}$ & $\begin{array}{l}\text { Total } \\
(\mathrm{d}=\mathrm{a}+\mathrm{b}+\mathrm{c})\end{array}$ & $\begin{array}{l}\text { Leaf } \\
\text { (e) }\end{array}$ & $\begin{array}{l}\text { Stem } \\
\text { (f) }\end{array}$ & $\begin{array}{l}\text { Panicle } \\
\text { (g) }\end{array}$ & $\begin{array}{l}\text { Total } \\
(\mathrm{h}=\mathrm{e}+\mathrm{f}+\mathrm{g})\end{array}$ & & \\
\hline \multirow[t]{6}{*}{2011} & \multirow[t]{2}{*}{$\mathrm{N}$} & $\mathrm{ET}_{0}$ & 38.8 & 36.6 & 14.0 & 89.4 & 0.0 & 14.2 & 5.9 & 20.1 & 15.4 & 53.9 \\
\hline & & $\mathrm{ET}_{75}$ & 57.2 & 51.8 & 19.7 & 128.7 & 0.0 & 19.0 & 6.0 & 25.0 & 13.5 & 90.2 \\
\hline & \multirow[t]{2}{*}{$\mathrm{P}$} & $\mathrm{ET}_{0}$ & 3.9 & 10.6 & 2.0 & 16.5 & 0.0 & 5.2 & 0.9 & 6.1 & 1.1 & 9.3 \\
\hline & & $\mathrm{ET}_{75}$ & 5.4 & 18.0 & 2.4 & 25.8 & 0.0 & 8.2 & 1.2 & 9.3 & 1.0 & 15.5 \\
\hline & \multirow[t]{2}{*}{ K } & $\mathrm{ET}_{0}$ & 30.3 & 81.5 & 13.6 & 125.4 & 0.0 & 36.1 & 8.9 & 45.0 & 12.2 & 68.2 \\
\hline & & $\mathrm{ET}_{75}$ & 47.7 & 117.9 & 17.4 & 183.0 & 0.0 & 51.9 & 8.4 & 60.3 & 10.0 & 112.7 \\
\hline \multirow[t]{6}{*}{2012} & \multirow[t]{2}{*}{$\mathrm{N}$} & $\mathrm{ET}_{0}$ & 45.4 & 56.3 & 20.2 & 121.9 & 0.0 & 22.9 & 2.7 & 25.6 & 23.2 & 73.1 \\
\hline & & $\mathrm{ET}_{75}$ & 59.2 & 58.4 & 21.5 & 139.1 & 0.0 & 25.9 & 2.2 & 28.1 & 27.4 & 83.6 \\
\hline & \multirow[t]{2}{*}{$\mathrm{P}$} & $\mathrm{ET}_{0}$ & 4.2 & 14.0 & 2.8 & 21.0 & 0.0 & 6.7 & 0.4 & 7.1 & 1.8 & 12.1 \\
\hline & & $\mathrm{ET}_{75}$ & 5.8 & 14.4 & 2.9 & 23.1 & 0.0 & 6.2 & 0.3 & 6.5 & 2.4 & 14.2 \\
\hline & \multirow[t]{2}{*}{ K } & $\mathrm{ET}_{0}$ & 35.1 & 165.6 & 17.0 & 217.7 & 0.0 & 67.7 & 1.6 & 69.3 & 14.4 & 134.0 \\
\hline & & $\mathrm{ET}_{75}$ & 49.3 & 179.2 & 20.0 & 248.5 & 0.0 & 77.9 & 1.7 & 79.6 & 16.2 & 152.7 \\
\hline
\end{tabular}

in miscanthus. Excluding the plots under the SL soil in 2012 where crop senesced early in the season (Roncucci et al., 2014), on average N, P and K uptakes in autumn spanned from $86-130 \mathrm{~kg} \mathrm{~N}^{-1}, 16-24 \mathrm{~kg} \mathrm{P} \mathrm{ha}^{-1}$ and 130-230 kg K ha ${ }^{-1}$, respectively. These values are consistent with data reported by Cadoux et al. (2013) on 2-4 years old miscanthus grown in northern France, and by Himken et al. (1997) on a 6-year old miscanthus in Germany, on crops achieving around $25 \mathrm{Mg} \mathrm{ha}^{-1}$. On the other hand, with slightly higher dry yields (about 30 $\mathrm{Mg} \mathrm{ha}^{-1}$ ) on a 3-year old crop, Beale \& Long (1997) found higher $\mathrm{N}$ and $\mathrm{K}$ uptakes (200 and $380 \mathrm{~kg} \mathrm{ha}^{-1}$ respectively) compared to our data. In the Mediterranean environment, on high yielding (40 $\mathrm{Mg} \mathrm{ha}^{-1}$ ) miscanthus mature stands ( $>5$ year old) Nassi o Di Nasso et al. (2011b) found similar nitrogen uptake (120 kg $\mathrm{N}$ ha ${ }^{-1}$ ), while higher $\mathrm{P}$ and $\mathrm{K}$ uptakes $\left(45 \mathrm{~kg} \mathrm{P}^{-1}\right.$ and $270 \mathrm{~kg} \mathrm{~K} \mathrm{ha}^{-1}$ ) probably due to the different crop management and soil nutrient availability.

When considering the winter harvest, nutrient uptakes observed in this study are generally lower than literature data, particularly for nitrogen. Over a 10-year study in UK, Christian et al. (2008) gave N, P and K uptakes to be around 76, 6 and $89 \mathrm{~kg} \mathrm{ha}^{-1}$, respectively. Nevertheless, with aboveground dry yields in winter around 15-20 Mg ha ${ }^{-1}$, nutrient uptakes comparable to our data have been observed by Strullu et al. (2011) and Himken et al. (1997).

To date, no studies have investigated the role of the water availability on miscanthus nutrient uptakes. Nevertheless, it is recognized how rainfall or irrigation can affect nutrients in plants (Lambers et al., 2008; Marschner \& Rengel, 2012). Our results suggested a partial influence of the irrigation on miscanthus nutrient uptake, particularly for $\mathrm{N}$ and $\mathrm{K}$ in autumn, when higher values were recorded on 2-year old crops receiving irrigation as compared to rainfed.

In addition, the role of the soil texture was evident in 2012 where miscanthus grown on the coarser soil (i.e. sandy-loam soil) showed nutrient uptakes as low as $12.5 \mathrm{~kg} \mathrm{~N} \mathrm{ha}^{-1}, 1.2 \mathrm{~kg} \mathrm{P} \mathrm{ha}^{-1}$ and $15.7 \mathrm{~kg} \mathrm{~K} \mathrm{ha}^{-1}$, confirming data obtained by Kering et al. (2012) on a young miscanthus plantation growing on a poor sandy-loam soil in Oklahoma (USA).

From our study, it also resulted that $\mathrm{N}$ fertilization influenced nutrient uptakes mainly in autumn, while differences became smoothed in winter. This behavior is supported by Himken et al. (1997) who observed significantly higher $\mathrm{N}$ uptake with higher $\mathrm{N}$ fertilization rates in November, while no differences resulted in February. Similarly, in a three-year old miscanthus, Strullu et al. (2011) found a significantly higher nitrogen uptake in fertilized treatments than in nonfertilized during the crop development (May-October), while no differences were reported in winter time (February).

Finally, we attempted to quantitate the remobilization of nutrients when delaying the harvest from autumn to winter. Nutrient remobilization is an effective survival strategy for perennial rhizomatous grasses (Himken et al., 1997; Heaton et al., 2009) and it thus represents an environmental friendly strategy to reduce fertilizer applications (Rowe et al., 2009). We found that postponed harvest led to nutrient savings as high as $80 \%$ for $\mathrm{N}$, and $65 \%$ for $\mathrm{P}$ and $\mathrm{K}$. This figure is substantially higher than Kahle et al. (2001) and Strullu et al. (2011). In fact, when switching from autumn to winter, ma- 
cronutrients in the aboveground biomass were significantly reduced through leaf litter (around 10\%) and mainly through remobilization and/or leaching (around $60 \%$ ). However, significant leaching is likely to occur for $\mathrm{K}$ only, as, among the macronutrients, its form in the biomass is mainly as a soluble ion (Jørgensen, 1997; Eichert \& Fernández, 2012).

In conclusion, our experimental framework allowed us to obtain novel information on miscanthus nutrient concentrations and uptakes on young miscanthus crops established in the Mediterranean. Overall, miscanthus was confirmed to be a relatively low input crop: $\mathrm{N}, \mathrm{P}$ and $\mathrm{K}$ uptakes in autumn were around 120, 20 and $190 \mathrm{~kg} \mathrm{ha}^{-1}$, respectively, with aboveground dry yields around $25 \mathrm{Mg} \mathrm{ha}^{-1}$. Moreover, considering a 30-35\% reduction in the harvestable biomass, the amount of nutrients removed from the field through a winter harvest can be substantially reduced to 25,7 and $60 \mathrm{~kg} \mathrm{ha}^{-1}$ for N, P and K, respectively. In fact, delayed harvest allowed a relevant remobilization of nutrients, up to $80 \%$, in the belowground biomass and an additional transfer of nutrients to soil through the litterfall.

Since crop management can significantly affect miscanthus nutrient uptakes when early harvests are performed, nitrogen fertilization in Mediterranean environments should be kept as low as possible, and based on balancing offtakes at harvest with nutrient inputs. Further studies should investigate the environmental (e.g. GHG emissions, energy balance, nutrient leaching etc.) and socio-economic (e.g. costs, land use etc.) aspects of higher yields-higher nutrient requirements (i.e. autumn harvest) vs. lower yields-lower nutrient requirements (i.e. winter harvest).

\section{Acknowledgements}

This study has been partly funded under the EU seventh Framework Programme by the LogistEC project $N^{\circ} 311858$ : Logistics for Energy Crops' Biomass. The views expressed in this work are the sole responsibility of the authors and do not necessary reflect the views of the European Commission.

A special thank is also due to the technical staff of the CRIBE and of the Institute of Life Sciences, Fabio Taccini, Sergio Cattani, and the Land Lab group within the Institute of Life Sciences, particularly Federico Triana, Simona Bosco, Ricardo Villani, Valentina Giulietti, Federico Dragoni and Maria Valentina Lasorella for their help the field work, and their valuable comments and suggestions.

\section{References}

Alam SM (1999) Nutrient uptake by plants under stress conditions. In: Handbook of Plant and Crop Stress (ed. Pessarakli M), pp. 285-314. CRC Press Florida, USA.

Allen RG, Pereira LS, Raes D, Smith M (1998) Crop Evapotranspiration - Guidelines for Computing Crop Water Requirements - FAO Irrigation and Drainage Paper 56. FAO, Rome, Italy.

Anderson-Teixeira KJ, Davis SC, Masters MD, Delucia EH (2009) Changes in soil organic carbon under biofuel crops. Global Change Biology Bioenergy, 1, 75-96.
Baxter XC, Darvell LI, Jones JM, Barraclough T, Yates NE, Shield I (2014) Miscanthus combustion properties and variations with Miscanthus agronomy. Fuel, 117, Part A, 851-869.

Beale CV, Long SP (1997) Seasonal dynamics of nutrient accumulation and partitioning in the perennial C4-grasses Miscanthus $\times$ giganteus and Spartina cynosuroides. Biomass and Bioenergy, 12, 419-428.

Boehmel C, Lewandowski I, Claupein W (2008) Comparing annual and perennial energy cropping systems with different management intensities. Agricultural Systems, 96, 224-236.

Bradstreet RB (1965) The Kjeldahl Method for Organic Nitrogen. Academic Press, New York, NY, USA.

Cadoux S, Riche AB, Yates NE, Machet J-M (2012) Nutrient requirements of Miscanthus $\times$ giganteus: conclusions from a review of published studies. Biomass and Bioenergy, 38, 14-22.

Cadoux S, Ferchaud F, Demay C et al. (2013) Implications of productivity and nutrient requirements on greenhouse gas balance of annual and perennial bioenergy crops. Global Change Biology Bioenergy, 6, 425-438

Chapin FS III (1991) Effects of multiple environmental stresses on nutrient availability and use. In: Response of Plants to Multiple Stresses (eds Mooney HA, Winner WE, Pell EJ), pp. 67-88. Academic Press, San Diego, USA.

Christian DG, Riche AB (1998) Nitrate leaching losses under Miscanthus grass planted on a silty clay loam soil. Soil Use and Management, 14, 131-135.

Christian DG, Riche AB, Yates NE (2008) Growth, yield and mineral content of Miscanthus $\times$ giganteus grown as a biofuel for 14 successive harvests. Industrial Crops and Products, 28, 320-327.

Chum H, Faaij A, Moreira J et al. (2011) Bioenergy. In: IPCC Special Report on Renewable Energy Sources and Climate Change Mitigation (eds Edenhofer O, Pichs-Madruga R, Sokona Y, Seyboth K, Matschoss P, Kadner S, Zwickel T, Eickemeier P, Hansen G, Schlömer S, von Stechow C), pp. 209-332. Cambridge University Press, Cambridge, UK and New York, USA.

Cordell D, Drangert J-O, White S (2009) The story of phosphorus: global food security and food for thought. Global Environmental Change, 19, 292-305.

Crutzen PJ, Mosier AR, Smith KA, Winiwarter W (2008) $\mathrm{N}_{2} \mathrm{O}$ release from agro-biofuel production negates global warming reduction by replacing fossil fuels. Atmospheric Chemistry and Physics, 8, 389-395.

Davis SC, Boddey RM, Alves BJR et al. (2013) Management swing potential for bioenergy crops. Global Change Biology Bioenergy, 5, 623-638.

Dohleman FG, Heaton EA, Arundale RA, Long SP (2012) Seasonal dynamics of above- and below-ground biomass and nitrogen partitioning in Miscanthus $\times$ giganteus and Panicum virgatum across three growing seasons. Global Change Biology Bioenergy, 4, 534-544.

Eichert T, Fernández V (2012) Uptake and release of elements by leaves and other aerial plant parts. In: Marschner's Mineral Nutrition of Higher Plants, 3rd edn (ed. Marschner P), pp. 71-84. Elsevier, Amsterdam, the Netherlands.

Gomez KA, Gomez AA (1984) Statistical Procedures for Agricultural Research. Wiley, New York, NY, USA.

Heaton EA, Dohleman FG, Long SP (2009) Seasonal nitrogen dynamics of Miscanthus $\times$ giganteus and Panicum virgatum. Global Change Biology Bioenergy, 1, 297-307.

Himken M, Lammel J, Neukirchen D, Czypionka-Krause U, Olfs HW (1997) Cultivation of Miscanthus under west European conditions: seasonal changes in dry matter production, nutrient uptake and remobilization. Plant and Soil, 189, 117-126.

Jørgensen U (1997) Genotypic variation in dry matter accumulation and content of $\mathrm{N}, \mathrm{K}$ and $\mathrm{Cl}$ in Miscanthus in Denmark. Biomass and Bioenergy, 12, 155-169.

Kahle P, Beuch S, Boelcke B, Leinweber P, Schulten HR (2001) Cropping of Miscanthus in Central Europe: biomass production and influence on nutrients and soil organic matter. European Journal of Agronomy, 15, 171-184.

Karp A, Richter GM (2011) Meeting the challenge of food and energy security. Journal of Experimental Botany, 62, 3263-3271.

Karp A, Shield I (2008) Bioenergy from plants and the sustainable yield challenge. New Phytologist, 179, 15-32.

Kering MK, Butler TJ, Biermacher JT, Guretzky JA (2012) Biomass yield and nutrient removal rates of perennial grasses under nitrogen fertilization. Bioenergy Research, $5,61-70$.

Kludze H, Deen B, Dutta A (2013) Impact of agronomic treatments on fuel characteristics of herbaceous biomass for combustion. Fuel Processing Technology, 109, 96-102.

Lambers H, Chapin FS III, Pons TL (2008) Plant Physiological Ecology, 2nd edn. Springer Verlag, New York.

Larsen S, Jørgensen U, Kjeldsen J, Lærke P (2013) Long-term miscanthus yields influenced by location, genotype, row distance, fertilization and harvest season. Bioenergy Research, 7, 620-635. 
Lewandowski I, Kicherer A (1997) Combustion quality of biomass: practical relevance and experiments to modify the biomass quality of Miscanthus $\times$ giganteus. European Journal of Agronomy, 6, 163-177.

Lewandowski I, Clifton-Brown JC, Scurlock JMO, Huisman W (2000) Miscanthus: European experience with a novel energy crop. Biomass and Bioenergy, 19, 209-227.

Lewandowski I, Scurlock JMO, Lindvall E, Christou M (2003a) The development and current status of perennial rhizomatous grasses as energy crops in the US and Europe. Biomass and Bioenergy, 25, 335-361.

Lewandowski I, Clifton-Brown JC, Andersson B et al. (2003b) Environment and harvest time affects the combustion qualities of genotypes. Agronomy Journal, 95, 1274-1280.

Marschner P, Rengel Z (2012) Nutrient availability in soils. In: Marschner's Mineral Nutrition of Higher Plants, 3rd edn (ed. Marschner P), pp. 315-330. Elsevier, Amsterdam, the Netherlands.

de Mendiburu F (2013) agricolae: statistical procedures for agricultural research. $\mathrm{R}$ package version 1.1-4. Available at: http://CRAN.R-project.org/package=agricolae (accessed 2510 2013)

Monti A, Di Virgilio N, Venturi G (2008) Mineral composition and ash content of six major energy crops. Biomass and Bioenergy, 32, 216-223.

Nassi o Di Nasso N, Roncucci N, Triana F, Taccini F, Ragaglini G, Bonari E (2011a) Giant reed (Arundo donax L.) and miscanthus (Miscanthus x giganteus Greef et Deuter) as energy crops in Mediterranean environment: growth analysis and nutrients content Biomass and Energy Crops IV. Aspects of Applied Biology, 112, 75-82.

Nassi o Di Nasso N, Roncucci N, Triana F, Tozzini C, Bonari E (2011b) Seasonal nutrient dynamics and biomass quality of giant reed (Arundo donax L.) and $\mathrm{mi}$ scanthus (Miscanthus $\times$ giganteus Greef et Deuter) as energy crops. Italian Journal of Agronomy, 6, 152-158.

Nassi o Di Nasso N, Roncucci N, Bonari E (2013) Seasonal dynamics of aboveground and belowground biomass and nutrient accumulation and remobilization in gian reed (Arundo donax L.): a three-year study on marginal land. Bioenergy Research, 6 , 725-736.

R Core Team (2013) R: A language and environment for statistical computing.R Foundation for Statistical Computing, Vienna, Austria. Available at: http:// www.R-project.org/ (accessed 136 2013).

Roncucci N, Nassi o Di Nasso N, Bonari E, Ragaglini G (2014) Influence of soil texture and crop management on the productivity of miscanthus (Miscanthus $\times g i-$ ganteus Greef et Deu.) in the Mediterranean. Global Change Biology Bioenergy. doi: $10.111 /$ gcbb.12202.
Rowe RL, Street NR, Taylor G (2009) Identifying potential environmental impacts of large-scale deployment of dedicated bioenergy crops in the UK. Renewable and Sustainable Energy Reviews, 13, 271-290.

Schwarz H, Liebhard P, Ehrendorfer K, Ruckenbauer P (1994) The effect of fertilization on yield and quality of Miscanthus sinensis 'Giganteus'. Industrial Crops and Products, 2, 153-159.

Smith R, Slater FM (2010) The effects of organic and inorganic fertilizer applications to Miscanthus $\times$ giganteus, Arundo donax and Phalaris arundinacea, when grown as energy crops in Wales, UK. Global Change Biology Bioenergy, 2, 169-179.

Smith R, Slater FM (2011) Mobilization of minerals and moisture loss during senescence of the energy crops Miscanthus $\times$ giganteus, Arundo donax and Phalaris arundinacea in Wales, UK. Global Change Biology Bioenergy, 3, 148-157.

Strullu L, Cadoux S, Preudhomme M, Jeuffroy MH, Beaudoin N (2011) Biomass production and nitrogen accumulation and remobilisation by Miscanthus $\times$ giganteus as influenced by nitrogen stocks in belowground organs. Field Crops Research, 121, 381-391.

\section{Supporting Information}

Additional Supporting Information may be found in the online version of this article:

Table S1. Results of the ANOVA in Experiment 1 (contrasting soil textures) for miscanthus aboveground nutrient uptakes in year 2011 and 2012 (i.e. second and third growing seasons respectively).

Table S2. Results of the ANOVA in Experiment 2 (contrasting irrigation regimes) for miscanthus aboveground nutrient uptakes in year 2011 and 2012 (i.e. second and third growing seasons respectively) 